\title{
Erratum to: Insight into the evolutionary history of symbiotic genes of Robinia pseudoacacia rhizobia deriving from Poland and Japan
}

Bożena Mierzwa • Barbara Lotocka •

Sylwia Wdowiak-Wróbel · Michał Kalita •

Sebastian Gnat · Wanda Małek

Published online: 5 May 2010

(C) Springer-Verlag 2010

Erratum to: Arch Microbiol (2010) 192:341-350

DOI 10.1007/s00203-010-0561-0

Unfortunately, one of the co-author names (Dr. Barbara Lotocka) was missed in the article. The correct author group should be:

"Bożena Mierzwa, Barbara Łotocka, Sylwia WdowiakWróbel, Michał Kalita, Sebastian Gnat, Wanda Małek".

Dr. Barbara Łotocka address is: Department of Botany, Faculty of Agriculture and Biology, Warsaw University of Life Sciences, SGGW, Nowoursynowska 159, 02-766 Warsaw, Poland.

The online version of the original article can be found under doi:10.1007/s00203-010-0561-0.

B. Mierzwa $\cdot$ S. Wdowiak-Wróbel $\cdot$ M. Kalita $\cdot$ S. Gnat ·

W. Małek $(\bowtie)$

Department of Genetics and Microbiology,

M. Curie-Skiodowska University, Akademicka 19 St.,

20-033 Lublin, Poland

e-mail: wanda.malek@poczta.umcs.lublin.pl

B. Łotocka

Department of Botany, Faculty of Agriculture and Biology,

Warsaw University of Life Sciences, SGGW,

Nowoursynowska 159, 02-766 Warsaw, Poland 